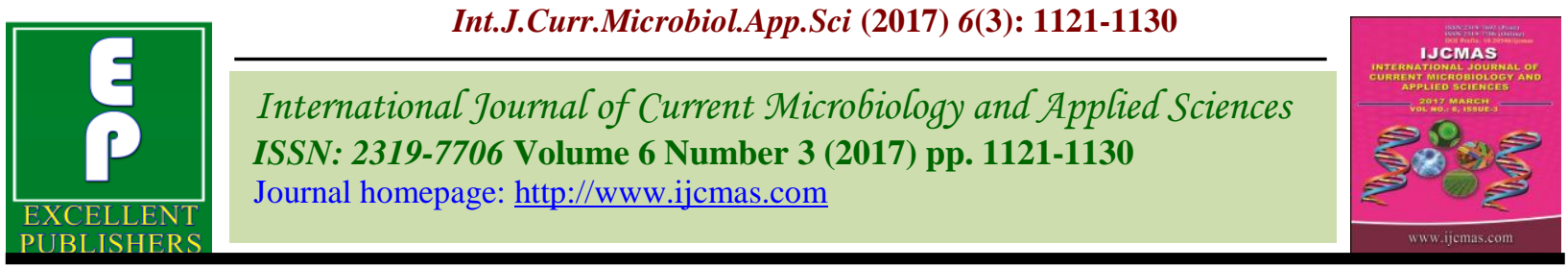

Original Research Article

https://doi.org/10.20546/ijcmas.2017.603.130

\title{
Releasing Characteristics of Potassium in Some Coastal Soils of West Bengal
}

\author{
Ranajit Panda ${ }^{1}$ and Sanmay Kumar Patra ${ }^{2}$ \\ ${ }^{1}$ RRS (OAZ), Majhian, UBKV, West Bengal, 733133, India \\ ${ }^{2}$ Bidhan Chandra Krishi Viswavidyalaya, Mohanpur, Nadia, West Bengal-741252, India \\ *Corresponding author
}

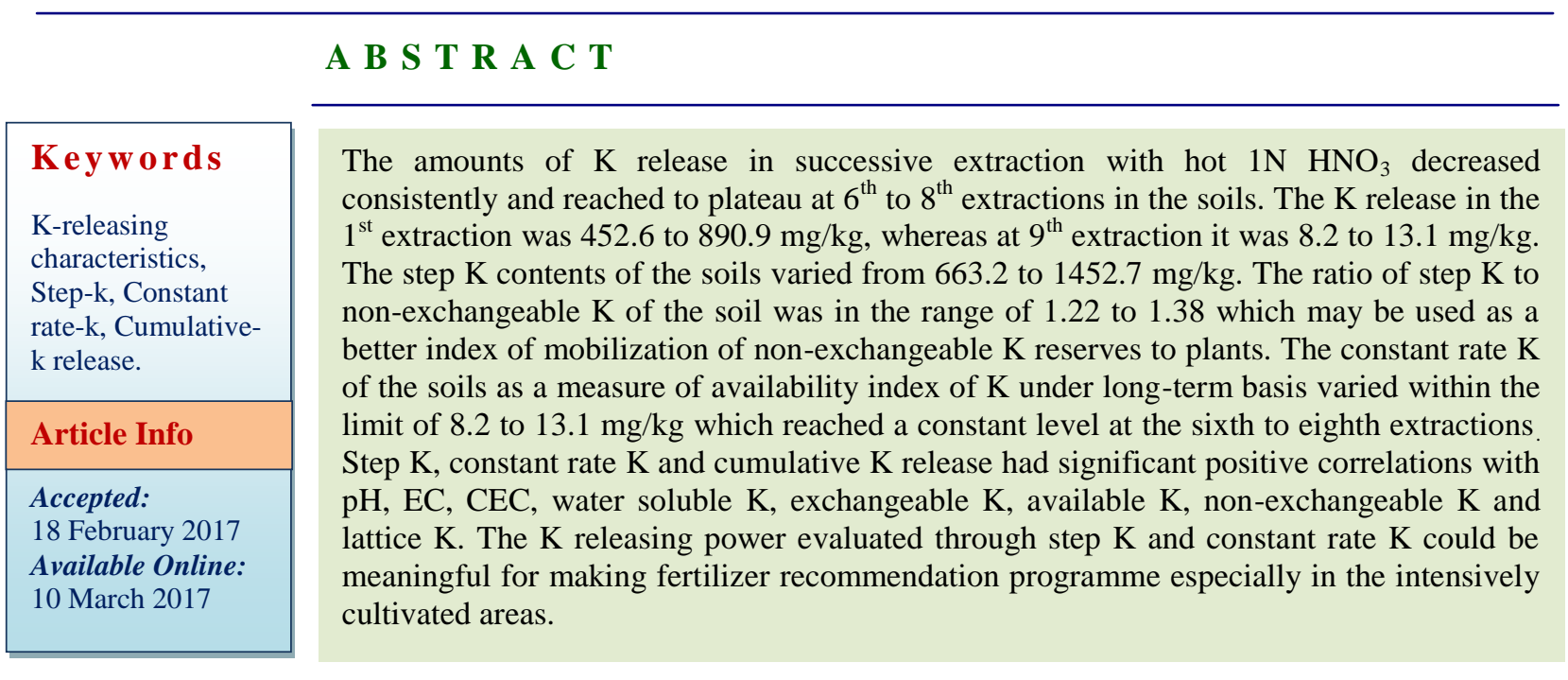

\section{Introduction}

Potassium occurs in soil in various forms and combinations and their releasing behavior to plants also differs widely. The releasing power of soil potassium is an index of the availability of the nutrient to the crops over a longer duration and in general, it indicates the sum of water soluble $\mathrm{K}$, exchangeable $\mathrm{K}$ and a fraction of non-exchangeable $\mathrm{K}$ which is not immediately available to the growing plants, but will be slowly available over a long period of time (Nash, 1971). Thus the K releasing power refers to the total $\mathrm{K}$ availability $\mathrm{K}$ in soil equivalent to the actual amount absorbed by plants. Several empirical, physiochemical and biological methods have been employed from time to time in devising better methods of potassium releasing vis-àvis potassium supplying power of soils and in comprehending the $\mathrm{K}$ release characteristics under varying soil, environmental and cropping conditions. One-time extraction or repeated extraction with boiling $1 \mathrm{M} \mathrm{HNO}_{3}$ has been suggested as one of the methods to assess the potassium supplying power of soils. In this connection, step $\mathrm{K}$ and constant rate $\mathrm{K}$ as proposed by Haylock (1956) measures the $\mathrm{K}$ releasing capacity of soils more effectively under intensive crop cultivation. Step $\mathrm{K}$ is the relatively soluble fraction of soil $\mathrm{K}$ and actually estimates the plant utilizable nonexchangeable $\mathrm{K}$. The constant rate $\mathrm{K}(\mathrm{CR}-\mathrm{K})$ measures the difficulty fraction of soil $\mathrm{K}$ and 
gives an idea about the rate of $\mathrm{K}$ release form mineral lattice under long-term cropping conditions. The feasibility of these parameters to measure the $\mathrm{K}$ releasing capacity of different soils under intensive crop cultivation was evaluated by several workers (Patra et al., 2008).

In the coastal soils of West Bengal, different soil types mainly under the order of Entisols and Inceptisols are prevalent in humid subtropical environment. These soils were put under different cropping programme without adequate attention to fertilizer $\mathrm{K}$ application assuming these soils are inherently rich in $\mathrm{K}$. Hence, the soils are likely to be depleted K from high to medium status and response of crops to $\mathrm{K}$ application has been increasingly noticed. In view of these facts, the present investigation was carried out to assess the $\mathrm{K}$ releasing power of soils evaluated through step $\mathrm{K}$ and constant rate $\mathrm{K}$ for predicating $\mathrm{K}$ supplying capacity of these soils for formulating more precise $\mathrm{K}$ fertilizer recommendations.

\section{Materials and Methods}

Out of forty representative surface $(0-0.20 \mathrm{~m})$ soil samples collected from different locations of coastal West Bengal, only eighteen samples having different physical and chemical properties and forms of potassium were selected for the study. These soils were cleaned, air-dried in shade and ground to pass through a $2 \mathrm{~mm}$ sieve was used in the experiment. The potassium releasing parameters such as step $\mathrm{K}$, constant rate $\mathrm{K}$ and cumulative release $\mathrm{K}$ were derived as per the procedure of Haylock (1956) using I N boiling $\mathrm{HNO}_{3}$ as an extractant. Constant rate $\mathrm{K}$ was taken at a stage when similar amounts of $\mathrm{K}$ were extracted in consecutive extractions, whereas step $\mathrm{K}$ was computed by subtracting the constant rate $\mathrm{K}$ values from the $\mathrm{K}$ extracted in each extraction and by summation of all those values. Cumulative release $\mathrm{K}$ is the sum of the values of $\mathrm{K}$ extracted in all the 10 extractions.

\section{Determination of $\mathbf{K}$ releasing power of soil}

Potassium releasing power of soil measured through step $\mathrm{K}$ and constant rate $\mathrm{K}$ was estimated by the method proposed by Haylock (1956), wherein boiling $1 \mathrm{~N} \mathrm{HNO}_{3}$ was used as an extractant. In this method $5 \mathrm{~g}$ of soil was consecutively extracted by boiling $50 \mathrm{ml}$ of $1 \mathrm{~N} \mathrm{HNO}_{3}$ (soil: extractant ratio 1:10) for 15 minutes. The successive extractions of the soil with the same reagent were continued till a stage reached when $\mathrm{K}$ was released, more or less, at a constant rate. This form of $\mathrm{K}$ was designated by Haylock as constant rate K. Step K was determined by subtracting the constant rate $\mathrm{K}$ from the amount of $\mathrm{K}$ released in each step of successive extractions and adding up all the values thus obtained after initial removal of water soluble $\mathrm{K}$ and exchangeable $\mathrm{K}$ (Maclean, 1961).

\section{Results and Discussion}

\section{Potassium releasing power of soils}

The amounts of soil $\mathrm{K}$ release in ten extractions schedule with boiling $1 \mathrm{~N} \mathrm{HNO}_{3}$ from the eighteen cultivated soils of the coastal region belonging to two soil orders have been presented in Table1, for the representative soils. The results showed that with successive extraction the amount of $\mathrm{K}$ release decreased step wisely in all the soils and reached to a plateau at $6^{\text {th }}$ to $8^{\text {th }}$ extractions. The amounts of $\mathrm{K}$ release in the $1^{\text {st }}$ extraction from different coastal soils varied widely and ranged from 452.6 to 890.9 $\mathrm{mg} / \mathrm{kg}$ whereas at $9^{\text {th }}$ extraction the amounts of $\mathrm{K}$ release, irrespective of soils, varied little within a range of 8.2 to $13.1 \mathrm{mg} / \mathrm{kg}$. As a whole, the first extraction constituted about 
60.8 per cent, the first and second extractions about 79.8 per cent and the first, second and third extractions about 88.9 per cent of total $\mathrm{K}$ release from soils. It is evident from the results that the absolute quantities of $\mathrm{K}$ released in successive extractions were not always proportional to the amounts of fixed soil $\mathrm{K}$ reserves, probably due to the variations in physicochemical, chemical and mineralogical characteristics of the soils. In the first extraction, the soils of Medinipur East district, on an average, released the highest quantity of K $(879.6 \mathrm{mg} / \mathrm{kg})$, contributing 57.7 per cent of total $\mathrm{K}$ release, followed by that of the soils of North 24 Parganas district $(820.9 \mathrm{mg} / \mathrm{kg})$ contributing 60.8 per cent of total $\mathrm{K}$ release and the least quantity of $\mathrm{K}$ was released from the soils of South 24 Parganas district $(637.6 \mathrm{mg} / \mathrm{kg})$ which contributed 63.1 per cent of total $\mathrm{K}$ release. The amount of release $\mathrm{K}$ from individual soil indicates that Potashpur soil from the Medinipur East district released maximum amount of $\mathrm{K}$, whereas minimum amount of $\mathrm{K}$ was released by Akshyanagar soil from South 24 Parganas district. In general, in the initial stages of repeated extraction, the stepwise decrease was more in those soils which released higher quantities of $\mathrm{K}$ in the first extraction as compared to those soils releasing lower amounts of $\mathrm{K}$. The plausible reasons for such variations in releasing differential quantities of $\mathrm{K}$ was the variability in the contents of K-bearing minerals in soil fractions and the tenacity with which $\mathrm{K}$ is being held in the mineral fabrics. The first group consisting of nine soils from Medinipur East and North 24 Parganas districts excepting Bholakhali soil was found to contain the higher amounts of nonexchangeable $\mathrm{K}$ and fixed or lattice $\mathrm{K}$ reserves which might have been held $K$ with less tenacity and thereby released $\mathrm{K}$ rapidly. On the other hand, the second group consisting of only two soils from Akshyanagar and Kalinagar of South 24
Parganas district having relatively lower amounts of non-exchangeable $\mathrm{K}$ and lattice $\mathrm{K}$ was possibly held more tenaciously resulting in relatively less $\mathrm{K}$ release during the first extraction (Pal and Mukhopadhyay, 1992). Accordingly, the $\mathrm{K}$ releasing power was found to be higher in the first group of soils and the lesser in the later group of soils. The remaining six soils of South 24 Parganas district and lone soil of Bholakhali from North 24 Parganas district released the moderate amounts of $\mathrm{K}$ with boiling $1 \mathrm{~N}$ $\mathrm{HNO}_{3}$ and was thereby included in the medium category in terms of $\mathrm{K}$ release. This implies to the fact that the crop response to $\mathrm{K}$ fertilization in these coastal soils is likely to be different and careful monitoring of the soil test values is therefore needed while advocating fertilizer $\mathrm{K}$ recommendation. During the extraction schedule, the $\mathrm{K}$ release in first extraction primarily included water soluble $\mathrm{K}$, exchangeable $\mathrm{K}$ and a fraction of non-exchangeable $\mathrm{K}$ that was moderately available to the plants. On the other hand, in the successive advanced stages of extractions, more and more of the released $\mathrm{K}$ probably came either from difficulty available or fixed form or from structural K (Ramanathan, 1982). In a similar study, Sahu and Gutpa (1987) recorded the rate of release was rapid at the beginning but progressively slowed down that suggested the initial ease of desorption was followed by more difficult desorption phenomena. Different types of exchange sites in clay minerals such vermiculite, illite, etc have different desorption rates. The external planar surface sites and the edge sites release the $\mathrm{K}$ readily, while desorption of $\mathrm{K}$ from interlayer sites involves a low rate of diffusion.

The cumulative release pattern of nonexchangeable $\mathrm{K}$ in soils by boiling $1 \mathrm{~N} \mathrm{HNO}_{3}$ in successive exactions is presented in Table 2. Analysis of the data revealed that the soils of North 24 Parganas and Medinipur East 
districts excepting lone soil of Bholakhali from North 24 Parganas district were found to release higher amounts of $\mathrm{K}$ in the first extraction as well as after nine extractions. On the other hand, all the soils excepting Akshyanagar and Kalinagar soils of South 24 Parganas district and Bholakhali soil from North 24 Parganas district followed almost the same pattern, but released comparatively moderate amounts of $\mathrm{K}$. The remaining two soils (i.e. Akshyanagar and Kalinagar) from South 24 Parganas district released the lesser amounts of $\mathrm{K}$ in every step of extractions. Thus according to the total amount of $\mathrm{K}$ release up to ten extractions, the former group of soils was categorized into the highest order indicating greater reserves for $\mathrm{K}$ release from initially non-exchangeable forms under $\mathrm{K}$ stress and thereby expected to have the higher $\mathrm{K}$ supplying power of soils. The second ones were grouped under the moderate category indicating the medium $\mathrm{K}$ reserves and moderate $\mathrm{K}$ supplying power of the soils and are likely to be responsive to potassium fertilization. The third ones were in the lower order of $\mathrm{K}$ release and termed as the least category in terms of total release $\mathrm{K}$ from nonexchangeable sources. The results of the study thereby suggest that these coastal soils have varying capacity of releasing nonexchangeable $\mathrm{K}$ reserves to the soil solution especially when the labile pool of $\mathrm{K}$ i.e. solution and exchangeable $\mathrm{K}$ in soils reaches at a critical level under $\mathrm{K}$ stress situation which is subsequently utilized by the successive crops on long-term basis (Dhar and Sanyal, 2000).

\section{Step K}

By repeated extractions with boiling $1 \mathrm{~N}$ $\mathrm{HNO}_{3}$, two categories of non-exchangeable $\mathrm{K}$ were distinguished, namely 'Step K' which was determined by subtracting the 'constant rate $\mathrm{K}$ ' from the successive extractions and summing up of all the successive components
(Table 3), the step $\mathrm{K}$ values of the soils, designated as the plant utilizable nonexchangeable K (Haylock, 1956), progressively decreased with successive extractions to zero by the seventh to eighth extraction. The second one is 'Constant rate $\mathrm{K}^{\prime}(\mathrm{CR}-\mathrm{K})$ which occurred in similar amounts in each extraction for each soil. The amounts of step $\mathrm{K}$, irrespective of the soils, varied widely ranging from 663.2 to $1452.7 \mathrm{mg} / \mathrm{kg}$ (Table 4), the highest being in the soil of Potashpur in Medinipur East district and the lowest in the soil of Akshyanagar from South 24 Parganas district. The district-wise distribution of step $\mathrm{K}$ in soils ranged from 663.2 to $1072.9,1090.2$ to 1210.1 and 1346.5 to $1452.7 \mathrm{mg} / \mathrm{kg}$ with a mean value of 913.9 , 1238.7 and $1397.7 \mathrm{mg} / \mathrm{kg}$ for the soils of South 24 Parganas, North 24 Parganas and Medinipur East district, respectively. The variability of step $\mathrm{K}$ in these coastal soils followed almost the same trend as in nonexchangeable $\mathrm{K}$ reserves. However, the amount of step $\mathrm{K}$ exceeded the amount of non-exchangeable $\mathrm{K}$ for each soil measured by the conventional single extraction with boiling $1 \mathrm{~N}^{\mathrm{HNO}_{3}}$ (Mani and Sanyal, 1993). Thus, the more the amount of step $\mathrm{K}$ in soil, the more is expected to be the plant utilizable non-exchangeable $\mathrm{K}$. The ratio of step $\mathrm{K}$ to non-exchangeable $\mathrm{K}$ may be used as a better index of mobilization of non-exchangeable $\mathrm{K}$ reserves in different soils (Dhar and Sanyal, 2000). The values varied a little within the limit of 1.22 to 1.38. Accordingly, the Potashpur soil with high content of nonexchangeable $\mathrm{K}$ had the highest mobilized non-exchangeable $\mathrm{K}$ reserve, whereas Akshyanagar soil with low content of nonexchangeable $\mathrm{K}$ had the lowest mobilized non-exchangeable $\mathrm{K}$ reserve (Table 4 ). This proposition in the present study seems to reflect the quantum of total non-exchangeable $\mathrm{K}$ availability in soil and total $\mathrm{K}$ release for crop nutrition and hence needs exhaustive field investigations for confirmation. 
Table.1 Releasing pattern of $\mathrm{K}$ by successive extraction with boiling $1 \mathrm{~N} \mathrm{HNO}_{3}$

\begin{tabular}{lcccccccccc}
\hline \multirow{2}{*}{ Location of the soil } & \multicolumn{8}{c}{ Successive extraction with boiling $\mathbf{1}$ N HNO } & (mg/kgsoil) \\
\cline { 2 - 11 } & I & II & II & IV & V & VI & VII & VIII & IX & X \\
\hline South 24 Parganas & & & & & & & & & & \\
Akshyanagar & 452.6 & 132.8 & 67.3 & 29.5 & 18.7 & 11.5 & 8.2 & 8.2 & 8.2 & 8.2 \\
Kalinagar & 476.5 & 155.8 & 76.3 & 33.2 & 19.4 & 12.2 & 8.5 & 8.5 & 8.5 & 8.5 \\
Narayanpur & 691.2 & 183.3 & 87.5 & 41.1 & 20.8 & 11.8 & 9.1 & 9.1 & 9.1 & 9.1 \\
Meargheri & 683.3 & 178.2 & 81.5 & 38.4 & 21.2 & 12.9 & 8.9 & 8.9 & 8.9 & 8.9 \\
Kripakhali & 688.4 & 185.5 & 79.8 & 37.6 & 19.6 & 13.1 & 9.4 & 9.4 & 9.4 & 9.4 \\
Gosaba & 693.7 & 189.7 & 82.2 & 34.5 & 17.8 & 12.9 & 9.8 & 9.8 & 9.8 & 9.8 \\
Rudranagar & 682.2 & 192.1 & 88.4 & 35.3 & 18.9 & 12.7 & 9.9 & 9.9 & 9.9 & 9.9 \\
Kamalpur & 732.8 & 222.5 & 98.7 & 42.2 & 21.5 & 14.9 & 11.7 & 10.2 & 10.2 & 10.2 \\
North 24 Parganas & & & & & & & & & & \\
Bholakhali & 744.5 & 219.7 & 105.6 & 44.4 & 23.2 & 15.1 & 11.2 & 10.5 & 10.5 & 10.5 \\
Deuli & 872.8 & 293.2 & 143.7 & 62.2 & 25.4 & 16.8 & 13.5 & 12.9 & 12.1 & 12.1 \\
Hingalganj & 841.7 & 265.4 & 132.2 & 57.5 & 33.3 & 20.5 & 13.6 & 11.8 & 11.8 & 11.8 \\
Dhamakhali & 832.4 & 261.3 & 129.3 & 56.6 & 32.2 & 19.1 & 13.2 & 11.4 & 11.4 & 11.4 \\
Hasnabad & 821.2 & 252.1 & 125.7 & 58.3 & 31.4 & 18.2 & 12.9 & 11.1 & 11.1 & 11.1 \\
Gobindapur & 812.6 & 243.5 & 121.8 & 52.2 & 27.3 & 15.9 & 12.4 & 10.8 & 10.8 & 10.8 \\
Medinipur East & & & & & & & & & & \\
Potashpur & 890.9 & 332.3 & 167.2 & 71.3 & 38.2 & 24.6 & 18.2 & 14.8 & 13.1 & 13.1 \\
Hariharpur & 882.2 & 320.5 & 151.6 & 67.7 & 35.1 & 23.2 & 16.3 & 14.5 & 12.9 & 12.9 \\
Fatepur & 876.4 & 312.2 & 149.5 & 62.4 & 32.6 & 21.2 & 15.9 & 14.1 & 12.6 & 12.6 \\
Sarda & 869.1 & 298.3 & 141.1 & 59.3 & 29.2 & 19.1 & 15.3 & 13.5 & 12.3 & 12.3 \\
\hline
\end{tabular}

Table.2 Cumulative release of soil $\mathrm{K}$ in boiling $1 \mathrm{~N} \mathrm{HNO}_{3}$

\begin{tabular}{lcccccccccc}
\hline \multirow{2}{*}{ Location of the soil } & \multicolumn{8}{c}{ Cumulative K release in boiling 1 N HNO } & $(\mathbf{m g} / \mathbf{k g s o i l})$ \\
\cline { 2 - 10 } & I & II & II & IV & V & VI & VII & VIII & IX & X \\
\hline South 24 Parganas & & & & & & & & & & \\
Akshyanagar & 452.6 & 585.4 & 652.7 & 682.2 & 700.9 & 712.4 & 720.6 & 728.8 & 737.0 & 745.2 \\
Kalinagar & 476.5 & 632.3 & 708.6 & 741.8 & 761.2 & 773.4 & 781.9 & 790.4 & 798.9 & 807.4 \\
Narayanpur & 691.2 & 874.5 & 962.0 & 1003.1 & 1023.9 & 1035.7 & 1044.8 & 1053.9 & 1063.0 & 1072.1 \\
Meargheri & 683.3 & 861.5 & 943.0 & 981.4 & 1002.6 & 1015.5 & 1024.4 & 1033.3 & 1042.2 & 1051.1 \\
Kripakhali & 688.4 & 873.9 & 953.7 & 991.3 & 1010.9 & 1024.0 & 1033.4 & 1042.8 & 1052.2 & 1061.6 \\
Gosaba & 693.7 & 883.4 & 965.6 & 1000.1 & 1017.9 & 1030.8 & 1040.6 & 1050.4 & 1060.2 & 1070.0 \\
Rudranagar & 682.2 & 874.3 & 962.7 & 998.0 & 1016.9 & 1029.6 & 1039.5 & 1049.4 & 1059.3 & 1069.2 \\
Kamalpur & 732.8 & 955.3 & 1054.0 & 1096.2 & 1117.7 & 1132.6 & 1144.3 & 1154.5 & 1164.7 & 1174.9
\end{tabular}




\begin{tabular}{|c|c|c|c|c|c|c|c|c|}
\hline \multicolumn{9}{|c|}{ North 24 Parganas } \\
\hline Bholakhali & 744.5 & $964.2 \quad 1069.8$ & 1114.21137 .4 & 1152.5 & 1163.7 & 1174.2 & 1184.7 & 1195.2 \\
\hline Deuli & 872.8 & 1166.01309 .7 & 1371.91397 .3 & 1414.1 & 1427.6 & 1440.5 & 1452.6 & 1464.7 \\
\hline Hingalganj & 841.7 & $1107.1 \quad 1239.3$ & 1296.81330 .1 & 1350.6 & 1364.2 & 1376.0 & 1387.8 & 1399.6 \\
\hline Dhamakhali & 832.4 & 1093.71223 .0 & 1279.61311 .8 & 1330.9 & 1344.1 & 1355.5 & 1366.9 & 1378.3 \\
\hline Hasnabad & 821.2 & 1073.31199 .0 & 1257.31288 .7 & 1306.9 & 1319.8 & 1330.9 & 1342.0 & 1353.1 \\
\hline $\begin{array}{l}\text { Gobindapur } \\
\text { Medinipur East }\end{array}$ & 812.6 & 1056.11177 .9 & $1230.1 \quad 1257.4$ & 1273.3 & 1285.7 & 1296.5 & 1307.3 & 1318.1 \\
\hline Potashpur & 890.9 & $1223.2 \quad 1390.4$ & 1461.71499 .9 & 1524.5 & 1542.7 & 1557.5 & 1570.6 & 1583.7 \\
\hline Hariharpur & 882.2 & $1202.7 \quad 1354.3$ & 1422.01457 .1 & 1480.3 & 1496.6 & 1511.1 & 1524.0 & 1536.9 \\
\hline Fatepur & 876.4 & 1188.61338 .1 & 1400.51433 .1 & 1454.3 & 1470.2 & 1484.3 & 1496.9 & 1509.5 \\
\hline Sarda & 869.1 & 1167.41308 .5 & $1367.8 \quad 1397.0$ & 1416.1 & 1431.4 & 1444.9 & 1457.2 & 1469.5 \\
\hline
\end{tabular}

Table.3 Components of Step K in the experimental soils

\begin{tabular}{lcccccccc}
\hline \multirow{2}{*}{ Location of the soil } & \multicolumn{7}{c}{ Components of step K (mg/kgsoil) } \\
\cline { 2 - 9 } & I & II & II & IV & V & VI & VII & VIII \\
\hline South 24 Parganas & & & & & & & & \\
Akshyanagar & 444.4 & 124.6 & 59.1 & 21.3 & 10.5 & 3.3 & - & - \\
Kalinagar & 468.0 & 147.3 & 67.8 & 24.7 & 10.9 & 3.7 & - & - \\
Narayanpur & 682.1 & 174.2 & 78.4 & 32.0 & 11.7 & 2.7 & - & - \\
Meargheri & 674.4 & 169.3 & 72.6 & 29.5 & 12.3 & 4.0 & - & - \\
Kripakhali & 679.0 & 176.1 & 70.4 & 28.2 & 10.2 & 3.7 & - & - \\
Gosaba & 683.9 & 179.9 & 72.4 & 24.7 & 8.0 & 3.1 & - & - \\
Rudranagar & 672.3 & 182.2 & 78.5 & 25.4 & 9.0 & 2.8 & - & - \\
Kamalpur & 722.6 & 212.3 & 88.5 & 32.0 & 11.3 & 4.7 & 1.5 & - \\
North 24 Parganas & & & & & & & & \\
Bholakhali & 734.0 & 209.2 & 95.1 & 33.9 & 12.7 & 4.6 & 0.7 & - \\
Deuli & 860.7 & 281.1 & 131.6 & 50.1 & 13.3 & 4.7 & 1.4 & 0.8 \\
Hingalganj & 829.9 & 253.6 & 120.4 & 45.7 & 21.5 & 8.7 & 1.8 & - \\
Dhamakhali & 821.0 & 249.9 & 117.9 & 45.2 & 20.8 & 7.7 & 1.8 & - \\
Hasnabad & 810.1 & 241.0 & 114.6 & 47.2 & 20.3 & 7.1 & 1.8 & - \\
Gobindapur & 801.8 & 232.7 & 111.0 & 41.4 & 16.5 & 5.1 & 1.6 & - \\
Medinipur East & & & & & & & & \\
Potashpur & 877.8 & 319.2 & 154.1 & 58.2 & 25.1 & 11.5 & 5.1 & 1.7 \\
Hariharpur & 869.3 & 307.6 & 138.7 & 54.8 & 22.2 & 10.3 & 3.4 & 1.6 \\
Fatepur & 863.8 & 299.6 & 136.9 & 49.8 & 20.0 & 8.6 & 3.3 & 1.5 \\
Sarda & 856.8 & 286.0 & 128.8 & 47.0 & 16.9 & 6.8 & 3.0 & 1.2 \\
\hline
\end{tabular}


Table.4 Step K, Constant rate K and cumulative release K (mg/kg soil) of the experimental soils

\begin{tabular}{lccccc}
\hline $\begin{array}{l}\text { Location of } \\
\text { the soil }\end{array}$ & $\begin{array}{c}\text { Non- } \\
\text { exchangeable K }\end{array}$ & Step K & $\begin{array}{c}\text { Constant } \\
\text { rate K }\end{array}$ & $\begin{array}{c}\text { Cumulative } \\
\text { release K }\end{array}$ & $\begin{array}{c}\text { Step } \\
\text { K:NEK }\end{array}$ \\
\hline $\begin{array}{l}\text { South 24 Parganas } \\
\text { Akshyanagar }\end{array}$ & 534 & 663.2 & 8.2 & 745.2 & 1.24 \\
Kalinagar & 592 & 722.4 & 8.5 & 807.4 & 1.22 \\
Narayanpur & 756 & 981.1 & 9.1 & 1072.1 & 1.30 \\
Meargheri & 721 & 962.1 & 8.9 & 1051.1 & 1.33 \\
Kripakhali & 762 & 967.6 & 9.4 & 1061.6 & 1.27 \\
Gosaba & 794 & 972.0 & 9.8 & 1070.0 & 1.22 \\
Rudranagar & 784 & 970.2 & 9.9 & 1069.2 & 1.24 \\
Kamalpur & 869 & 1072.9 & 10.2 & 1174.9 & 1.23 \\
North 24 Parganas & & & & & \\
Bholakhali & 892 & 1090.2 & 10.5 & 1195.2 & 1.22 \\
Deuli & 983 & 1343.7 & 12.1 & 1464.7 & 1.37 \\
Hingalganj & 968 & 1281.6 & 11.8 & 1399.6 & 1.32 \\
Dhamakhali & 963 & 1264.3 & 11.4 & 1378.3 & 1.31 \\
Hasnabad & 949 & 1242.1 & 11.1 & 1353.1 & 1.31 \\
Gobindapur & 938 & 1210.1 & 10.8 & 1318.1 & 1.29 \\
Medinipur East & & & & & \\
Potashpur & 1050 & 1452.7 & 13.1 & 1583.7 & 1.38 \\
Hariharpur & 1022 & 1407.9 & 12.9 & 1536.9 & 1.38 \\
Fatepur & 1008 & 1383.5 & 12.6 & 1509.5 & 1.37 \\
Sarda & 982 & 1346.5 & 12.3 & 1469.5 & 1.37 \\
\hline
\end{tabular}

Table.5Coefficients of correlation of step K, constant rate $\mathrm{K}$ and cumulative release $\mathrm{K}$ with important soil properties and forms of soil $\mathrm{K}$

\begin{tabular}{|c|c|c|c|}
\hline Parameter & Step K & Constant rate $K$ & Cumulative release $\mathrm{K}$ \\
\hline Clay & 0.167 & 0.188 & 0.168 \\
\hline Silt & 0.230 & 0.263 & 0.233 \\
\hline Sand & -0.246 & -0.280 & -0.248 \\
\hline $\mathrm{pH}$ & $0.788^{* * *}$ & $0.747 * * *$ & $0.786^{* * *}$ \\
\hline EC & $0.854 * * *$ & $0.865^{* * * *}$ & $0.856 * * *$ \\
\hline CEC & $0.550 *$ & $0.471 *$ & $0.546^{*}$ \\
\hline Organic C & 0.376 & 0.242 & 0.368 \\
\hline Water soluble $\mathrm{K}$ & $0.927 * * *$ & $0.932 * * *$ & $0.928 * * *$ \\
\hline Exchangeable $\mathrm{K}$ & $0.940 * * *$ & $0.946^{* * *}$ & $0.942 * * *$ \\
\hline Available K & $0.942 * * *$ & $0.947 * * *$ & $0.944 * * *$ \\
\hline Non-exchangeable $\mathrm{K}$ & $0.985 * * *$ & $0.953 * * *$ & $0.985 * * *$ \\
\hline Lattice K & $0.961 * * *$ & $0.978 * * *$ & $0.964 * * *$ \\
\hline
\end{tabular}


The releasing pattern of step K or mobile nonexchangeable $\mathrm{K}$ showed that all the soils had three distinct regions (Table 1). The initial relatively long region with steep slope representing comparatively large amount of easily extractable $K$, the relatively long middle transitional region representing moderately available $\mathrm{K}$ and then the relatively flat portion representing $\mathrm{K}$ which was held more tenaciously and released $\mathrm{K}$ very slowly for plant use. Haylock (1956) suggested that the soils would become responsive to potassium fertilizer when step $\mathrm{K}$ is about 3.0 $\mathrm{me} / \mathrm{kg}$ soil or less and non-responsive when the value is about $5.0 \mathrm{me} / \mathrm{kg}$ soil or more. According to this proposition, the step $\mathrm{K}$ of the soils varied from 16.9 to $37.1 \mathrm{me} / \mathrm{kg}$ soil. These values appear to be very high in these coastal soils and thereby expected to be nonresponsive to $\mathrm{K}$ fertilization for a longer duration to the plants. In the present study, the soils of Medinipur East district, on average, showed the higher amounts of 'step $\mathrm{K}$ ' indicating greater release of $\mathrm{K}$ from nonexchangeable $\mathrm{K}$ reserves under stress situation for a longer duration, while the soils of North 24 Parganas district release K from non-exchangeable $\mathrm{K}$ sources for medium duration and the remaining soils of South 24 Parganas district are likely to be the least category and $\mathrm{K}$ will be depleted within short period under intensive cropping cycles.

The results pertaining in Table 5 show that step $\mathrm{K}$ had highly significant and positive correlations with soil $\mathrm{pH}\left(\mathrm{r}=0.788^{* * *}\right)$, EC $(\mathrm{r}=0.854 * * *)$, water soluble $\mathrm{K}(\mathrm{r}=0.927 * * *)$, exchangeable $\mathrm{K}(\mathrm{r}=0.940 * * *)$, available $\mathrm{K}(\mathrm{r}$ $\left.=0.942^{* * *}\right)$, non-exchangeable $\mathrm{K}(\mathrm{r}=$ $\left.0.985^{* * *}\right)$ and lattice $\mathrm{K}(\mathrm{r}=0.961 * * *)$ and significant and positive correlations with CEC $(\mathrm{r}=0.550 *)$, This implies that both the labile and non-labile pool of reserve $\mathrm{K}$ including the soil variables may play a predominant role in the enrichment of step $\mathrm{K}$ or mobilizable nonexchangeable $\mathrm{K}$ reserves in these soils.

\section{Constant rate potassium}

The constant rate $\mathrm{K}$ of the soils as a measure of availability index of $\mathrm{K}$ under long-term basis varied within the narrow limit of 8.2 to $13.1 \mathrm{mg} / \mathrm{kg}$ in spite of wide variations in step $\mathrm{K}$ contents of the soils (Table 4). These values accomplished a constant level at the sixth to eighth extractions with boiling $1 \mathrm{~N} \quad \mathrm{HNO}_{3}$ (Table 33, Figures 23 to 30), thereby indicating that there was still considerable amounts of $\mathrm{K}$ reserve even after the $8^{\text {th }}$ extractions and that had a definite solubility in hot $1 \mathrm{~N} \mathrm{HNO}_{3}$.

The release of $\mathrm{K}$ at constant rate started at sixth extraction in seven soils, at seventh extraction in seven soils and at eighth extraction in the remaining five soils. This suggests that the curtailment of $\mathrm{K}$ releasing power is likely to be quicker in the first group of soils, moderate in the second group of soils and slower in the later group of soils. Thus the former two groups of soils is expected to show low to moderate $\mathrm{K}$ supplying power than the latter which is likely to have relatively higher $\mathrm{K}$ supplying power. The constant rate $\mathrm{K}$ in the present group of soils indicates the presence of low to high level of 'structural $\mathrm{K}$ ' or 'interlayer $\mathrm{K}$ '. It is very slowly but constantly transformed into available form for the crops over a longer period under exhaustive cropping provided with no external supply of K fertilizers.

The coefficients of correlation between constant rate $\mathrm{K}$ and different soil properties and forms of $\mathrm{K}$ (Table 5) showed that the constant rate $\mathrm{K}$ had highly significant positive correlation with soil $\mathrm{pH}(\mathrm{r}=0.747 * * *), \mathrm{EC}(\mathrm{r}$ $\left.=0.865^{* * *}\right)$, water soluble $\mathrm{K}(\mathrm{r}=0.932 * * *)$, exchangeable $\mathrm{K}\left(\mathrm{r}=0.946^{* * *}\right)$, available $\mathrm{K}(\mathrm{r}$ $=0.947 * * *)$, non-exchangeable $\mathrm{K}(\mathrm{r}=$ $0.953 * * *)$ and lattice or structural $\mathrm{K}(\mathrm{r}=$ $0.978 * * *)$ and significant positive correlation with CEC $\left(\mathrm{r}=0.689^{*}\right)$, similar to that of step 
K. It had non-significant positive correlation with clay and silt and negative correlation with sand fraction.

\section{Cumulative $\mathrm{K}$ release}

The cumulative $\mathrm{K}$ release computed by the summation of $\mathrm{K}$ released up to tenth extractions is presented in Table 2 . The pattern of distribution of cumulative $\mathrm{K}$ release followed almost the same trend as in nonexchangeable $\mathrm{K}$, step $\mathrm{K}$ and constant rate $\mathrm{K}$. The amount of cumulative $\mathrm{K}$ release irrespective of soils varied from 745.2 to $1583.7 \mathrm{mg} / \mathrm{kg}$, the highest being in the soil of Potashpur of Medinipur East district and the lowest in the soil of Akshyanagar of South 24 Parganas district.

The district-wise distribution of cumulative $\mathrm{K}$ release from the soils of South 24 Parganas, North 24 Parganas and Medinipur East districts ranged from 745.2 to $1174.9,1195.2$ to 1464.7 and 1469.5 to 1583.7 with average values of $1006.4,1351.5$ and $1524.9 \mathrm{mg} / \mathrm{kg}$, respectively. Metson (1969) proposed that K extracted by several successive extractions with boiling $1 \mathrm{~N} \mathrm{HNO}_{3}$ in the same soil until a plateau is reached, would be a better measure of the $\mathrm{K}$ supplying power of soil.

According to this proposition, the $\mathrm{K}$ supplying power of the soils of North 24 Parganas and Medinipur East districts excluding the Bholakhali soil is likely to be higher than the soils of Akshyanagar and Kalinagar of South 24 Parganas district which is expected to be the lowest $\mathrm{K}$ supplying power. The remaining soils of South 24 Parganas district and the lone soil collected from Bholakhali of North 24 Parganas district is expected to be moderate or intermediate in $\mathrm{K}$ supplying power. So the crop responses to $\mathrm{K}$ fertilizer application in these soils are likely to be different. The results given in Table 5 revealed that the cumulative $\mathrm{K}$ release had highly significant positive correlation with soil $\mathrm{pH}\left(\mathrm{r}=0.786^{* * *}\right)$, EC $\left(\mathrm{r}=0.856^{* * *}\right)$, water soluble $\mathrm{K}(\mathrm{r}=0.928 * * *)$, exchangeable $\mathrm{K}\left(\mathrm{r}=0.942^{* * *}\right)$, available $\mathrm{K}(\mathrm{r}=0.944 * * *)$, non-exchangeable $\mathrm{K}\left(\mathrm{r}=0.985^{* * *}\right)$ and lattice or structural $\mathrm{K}\left(\mathrm{r}=0.964^{* * *}\right)$ and significant positive correlation with CEC $(\mathrm{r}=$ $\left.0.546^{*}\right)$. It also showed non-significant positive correlation with clay and silt and non-significant negative correlation with sand fraction.

A perusal of the results suggests that the present group of coastal soils have very high level of step $\mathrm{K}$ or plant utilizable nonexchangeable $\mathrm{K}$ and these soils expected to show non-responsive to K-fertilizer application. The constant rate $\mathrm{K}$, on the other hand, showed the low to moderate level of structural $\mathrm{K}$ or mineral $\mathrm{K}$, which will be slowly available to the growing crops for longer duration, provided with no external $\mathrm{K}$ application through fertilizers and manures.

However, the soils of North 24 Parganas and Medinipur East districts excepting Bholakhali soil with higher amounts of step $\mathrm{K}$ and constant rate $\mathrm{K}$ and six soils of South 24 Parganas district and lone soil from Bholakhali of North 24 Parganas district with moderate amounts of step $\mathrm{K}$ and constant rate $\mathrm{K}$ expected to be higher to moderate $\mathrm{K}$ releasing power as compared to the two $\mathrm{K}$ depleted soils from Akshyanagar and Kalinagar of South 24 Parganas district and crops can meet the entire $\mathrm{K}$ requirements at critical growth stages without any $\mathrm{K}$ application. On the contrary, the latter two soils having relatively lower amounts of step $\mathrm{K}$ and constant rate $\mathrm{K}$ is supposed to be lower $\mathrm{K}$ releasing power and moderate doses of $\mathrm{K}$ fertilizer administration is thereby needed for better crop nourishment and to prevent further drop of plant utilizable non-exchangeable $\mathrm{K}$ due to successive cropping. 


\section{References}

Dhar, A. and Sanyal, S.K. 2000. Nonexchangeable potassium reserves and their release pattern in some Alfisols and Inceptisols of West Bengal. J. Indian Soc. Soil Sci., 48(4): 741-747.

Dhar, A., Debnath A. and Sanyal, S.K. 2009. Planning judicious fertilization for maintaining native soil potassium reserves in an Ultic Paleustalf in relation to its uptake by rice and potato. J. Indian Soc. Soil Sci., 57 (1): 58-61.

Haylock, O.F. 1956. A method for estimating the availability of non-exchangeable potassium, Proc. $6^{\text {th }}$ Int. Congr. Soil Sci., 2: 403-408.

Mani, P.K. and Sanyal, S.K. 1993. Release pattern of non-labile potassium in some Entisols, Inceptisols, Mollisols and Alfisols of West Bengal. J. Indian Soc. Soil Sci., 41(4): 658662.
Metson, A.J. 1969. The long term potassium supplying power of Newzealand soils. Soil Sci., 11: 300-307.

Nash, V.E. 1971. Potassium release characteristics of some soils of the Mississippi coastal plain as revealed by various extracting agents. Soil Sci., 111(5): 313-317.

Pal, S.K. and Mukhopadhyay, A.K. 1990. Forms of potassium in some Alfisols of West Bengal. J. Pot. Res., 6(4): 180-184.

Patra, S.K., Ray, R. and Sahu, C. 2008. Potassium availability under variable moisture regimes in different rice soils of West Bengal. Environ. Ecol., 26(3): 1070-1073.

Ramanathan, K.M. and Krishnamoorthy, K.K. 1982. Potassium releasing power vis-a-vis potassium supplying power of soils. $J$. Indian Soc. Soil Sci., 30(2): 176-179.

Sahu, S. and Gupta, S.K. 1987. Fixation and release of potassium in some alluvial soils. J. Indian Soc. Soil Sci., 35(1): 29-34.

\section{How to cite this article:}

Ranajit Panda and Sanmay Kumar Patra. 2017. Releasing Characteristics of Potassium in Some Coastal Soils of West Bengal. Int.J.Curr.Microbiol.App.Sci. 6(3): 1121-1130. doi: https://doi.org/10.20546/ijcmas.2017.603.130 